\title{
In-hospital mortality in patients hospitalized with COVID-19 during the first wave of the pandemic in a Spanish community hospital.
}

\author{
Joan Carles Trullàs ${ }^{1}$, Eva Ruiz ${ }^{1}$, Clara Weisweiler ${ }^{2}$, Gemma Badosa $^{1}$, Alba Serra ${ }^{1}$, Hugo \\ Briceño $^{1}$, Silvia Soler ${ }^{1}$, and Josep Bisbe ${ }^{1}$ \\ ${ }^{1}$ Hospital d'Olot i comarcal de la Garrotxa \\ ${ }^{2}$ Universitat de Girona
}

October 5, 2020

\begin{abstract}
Abstract: Background: Spain is one of the European countries affected by the COVID-19 pandemic with a high number of recorded cases and deaths in Europe. Aim: To describe clinical characteristics and outcome of patients with COVID-19 hospitalized in a regional hospital in Spain. Methods: Clinical characteristics of the first COVID-19 patients hospitalised in the early days of the epidemic were recorded upon admission. A logistic regression multivariate analysis was performed to determine factors independently associated with a composite endpoint (death or ICU admission). Results: We included 100 patients, median age was 75 years and $52 \%$ were men. The most common comorbidities were hypertension (63\%), diabetes (22\%) and cardiovascular diseases (28\%). The most common symptoms were fever (80\%), cough (69\%), fatigue (59\%) and dyspnoea $(52 \%)$ and $64 \%$ had respiratory insufficiency. Bilateral interstitial infiltrates $(65 \%)$ and bilateral vertical "B-kerley" lines $(82.6 \%)$ were the most common findings in chest radiographs and lung ultrasound. All patients received supplementary oxygen, $69 \%$ received medical treatment (hydroxychloroquine plus azithromycin the most common regimen) and $12 \%$ glucocorticoids. During hospitalization, $26 \%$ died, $10 \%$ were transferred to ICU and the remaining $62 \%$ were discharged at home. In the multivariate analysis a higher comorbidity burden (OR 1.4; 95\% CI: 1.1-1.8) and higher C-reactive protein values on admission (OR 1.2; 95\% CI: 1.1-1.4) were independent risk factors for the composite endpoint. Conclusions: Case-fatality rate of patients hospitalized with COVID-19 in the early days of the Spanish epidemic was $26 \%$. A high comorbidity burden is associated to an increased risk of death or ICU admission.
\end{abstract}

\section{Original article}

Title: In-hospital mortality in patients hospitalized with COVID-19 during the first wave of the pandemic in a Spanish community hospital.

\section{Running title: In-hospital mortality due to COVID-19}

Authors : Joan Carles Trullàs ${ }^{1,2}$, Eva Ruiz ${ }^{1}$, Clara Weisweiler ${ }^{3}$, Gemma Badosa ${ }^{1}$, Alba Serra ${ }^{1}$, Hugo Briceño $^{1}$, Sílvia Soler ${ }^{1}$, Josep Bisbe ${ }^{1}$.

Affiliations : ${ }^{1}$ Internal Medicine Service, Hospital d'Olot i Comarcal de la Garrotxa, Girona (Spain). ${ }^{2}$ The Tissue Repair and Regeneration Laboratory (TR2Lab), Facultat de Medicina, Universitat de Vic - Universitat Central de Catalunya, Vic (Spain). ${ }^{3}$ Facultat de Medicina. Universitat de Girona, Girona (Spain)

Corresponding author : Joan Carles Trullàs, Internal Medicine Service, Hospital d'Olot i Comarcal de la Garrotxa. Address: Av dels Països Catalans, 86, 17800, Olot (Girona), Spain. Telephone: 0034+972261800. E-mail: jctv5153@comg.cat 
Acknowledgments: we thank Mercè Espejo and Montse Invernó for their administrative support and also Prof. Jose $\mathrm{M}^{\mathrm{a}}$ Miró for his always wise advice. No external funding was received.

Conflict of interest: none

Title: In-hospital mortality in patients hospitalized with COVID-19 during the first wave of the pandemic in a Spanish community hospital.

Abstract : Background : Spain is one of the European countries affected by the COVID-19 pandemic with a high number of recorded cases and deaths in Europe. Aim : To describe clinical characteristics and outcome of patients with COVID-19 hospitalized in a regional hospital in Spain. Methods : Clinical characteristics of the first COVID-19 patients hospitalised in the early days of the epidemic were recorded upon admission. A logistic regression multivariate analysis was performed to determine factors independently associated with a composite endpoint (death or ICU admission). Results : We included 100 patients, median age was 75 years and $52 \%$ were men. The most common comorbidities were hypertension $(63 \%)$, diabetes $(22 \%)$ and cardiovascular diseases (28\%). The most common symptoms were fever (80\%), cough (69\%), fatigue (59\%) and dyspnoea $(52 \%)$ and $64 \%$ had respiratory insufficiency. Bilateral interstitial infiltrates $(65 \%)$ and bilateral vertical "B-kerley" lines (82.6\%) were the most common findings in chest radiographs and lung ultrasound. All patients received supplementary oxygen, $69 \%$ received medical treatment (hydroxychloroquine plus azithromycin the most common regimen) and $12 \%$ glucocorticoids. During hospitalization, $26 \%$ died, $10 \%$ were transferred to ICU and the remaining $62 \%$ were discharged at home. In the multivariate analysis a higher comorbidity burden (OR 1.4; 95\% CI: 1.1-1.8) and higher C-reactive protein values on admission (OR 1.2; 95\% CI: 1.1-1.4) were independent risk factors for the composite endpoint. Conclusions : Case-fatality rate of patients hospitalized with COVID-19 in the early days of the Spanish epidemic was $26 \%$. A high comorbidity burden is associated to an increased risk of death or ICU admission.

Keywords : COVID-19; severe acute respiratory syndrome coronavirus 2

\section{What is already known about this topic?}

- There is a significant variation in the clinical characteristics and in-hospital mortality among patients diagnosed with COVID-19 across the globe.

- There is little information describing the characteristics and outcome of patients requiring hospitalization for COVID-19 in European regional hospitals

\section{What does this article add?}

- Our study includes and represents older patients, with a median age of 75 years old (range 28-96) and more than a third over 80 years old.

- We found a high in-hospital mortality (26\%), being notably higher than the reported at the beginning of the pandemic in China and the first communications from Italy and the United States.

- We found that a high burden of comorbidities and high C-reactive protein values were independent risk factors for mortality or ICU admission.

\section{Introduction}

A cluster of pneumonia of unknown origin was identified in Wuhan, China, in December $2019^{1}$. The disease (named coronavirus disease 2019 (COVID-19)) was caused by a novel coronavirus termed severe acute respiratory syndrome coronavirus 2 (SARS-CoV-2) and was declared a public health emergency of international concern by the World Health Organization (WHO) ${ }^{2}$. In the WHO European Region, COVID-19 surveillance was implemented on January 2020 and nine European countries reported 47 cases, being France and Germany the countries with more confirmed cases. At that time only two cases from Spain were reported ${ }^{3}$. Since then, larger series of cases from different countries (China, United States and Italy) and different settings (from long-term care facilities to intensive care units -ICU-) were reported with some differences in demographics, comorbidities and mortality rates ${ }^{4-7}$. 
In this study, we describe the clinical features and outcome of the first 100 sequentially admitted patients with laboratory confirmed COVID-19 to the Hospital de Olot i comarcal de la Garrotxa (HOCG), a regional hospital in Spain, during the first wave of the pandemic.

\section{Methods}

\section{Study design}

This is a prospective and observational study of the first patients with COVID-19 diagnosed in the HOCG, a regional hospital in Spain.

\section{Scope and study population}

The study was performed in the region of "La Garrotxa" (Girona, Spain). This is a rural region that belongs to the province of Girona (Spain) and has a total population of 57,590 inhabitants with remarkable aging ( $20 \%$ of the inhabitants have an age equal to or more than 65 years of age). The HOCG regional hospital has 136 hospital beds (64 for acute patient care and 72 for chronic care). Under normal conditions, no ICU beds are available, but exceptionally, operating room resuscitation was enabled to attend to a maximum of 4 critical patients. During the first wave of the pandemic $16 \%$ of our healthcare workers were affected by the disease $^{8}$.

\section{Study period}

The COVID-19-HOCG study started on March 16, 2020 after the diagnosis and admission of the first cases of COVID-19 in our centre and for the present analysis we have included the first 100 hospitalized cases.

\section{Inclusion and exclusion criteria}

This study includes all consecutive patients admitted to our hospital with a diagnosis of COVID-19. Only those patients who do not consent to participate in the study could be excluded. There were no other exclusion criteria.

\section{COVID-19 definition}

In order to diagnose a COVID-19 case, the criteria defined by the "Spanish Ministry of Health" on March 2020 were followed ${ }^{9}$. For the present study, only those cases with laboratory confirmation (PCR positive to any of the SARS-CoV-2 genes) were included.

\section{Data collection and study variables}

The following variables were collected and analysed: demographic data, cardiovascular risk factors, comorbidities, clinical presentation, analytical and radiological abnormalities (chest radiography, computed tomography -CT- and/or lung ultrasound -LUS-) and prescribed treatment during admission. The burden of comorbidities and one-year risk of death was calculated using the PROFUND score, that includes demographic, clinical, laboratory, social and functional variables, and establishes 4 levels of risk of death: low, intermediate, high and very high ${ }^{10}$. LUS abnormalities were classified using a score similar to that of Soldati et $\mathrm{al}^{11}$. Finally, we collected information about the outcome after admission (discharge, death, or transfer to the ICU).

\section{Statistical analysis}

Categorical variables are expressed as number of patients and percentages and quantitative variables as median and interquartile range [IQR]. The Kolmogorov-Smirnov test was used to determine whether quantitative variables were normally distributed. The Chi-square test $\left(\chi^{2}\right)$ was used to compare qualitative variables (when the expected number of cases in any of the cells was lower than 5, the Fisher exact test was used) and the Student's T test to compare normally distributed quantitative variables (the Mann-Whitney U test for the non-normally distributed ones). A logistic regression analysis was performed to assess variables associated with the composite end-point of mortality or ICU admission. This analysis was adjusted for variables that were statistically significant $(\mathrm{p}<0.05)$ in the bivariate analysis and those risk factors previously described in 
the literature (arterial hypertension and obesity). A 2-sided $\alpha$ of less than 0.05 was considered statistically significant. Analyses were performed with the software Statistical Package for Social Sciences (SPSS) version 20.0 (SPSS, Inc., Chicago, Illinois, USA).

Ethical considerations

The study complies with the Code of Ethics of the World Medical Association (Declaration of Helsinki). The Ethics Committee of the "Hospital Universitari Dr. Josep Trueta, Girona (Spain)" approved the study protocol and informed consent was obtained from all participating subjects. No patient refused to participate.

\section{Results}

As of April 20, 2020, there were 100 patients consecutively hospitalized with laboratory-confirmed COVID19 whose age distribution and baseline characteristics are summarized in Table 1 . Most patients had advanced age with a median of 75 years old (range 28-96) and more than $61 \%$ were older than 70 years old. There was a high burden of comorbidities, the most frequent being hypertension (63\%), diabetes mellitus $(22 \%)$ and different cardiovascular diseases including heart, cerebrovascular and peripheral artery diseases (28\%). There was a high risk for mortality according to the PROFUND score. In contrast, few patients were active of former smokers or had other conditions such as chronic respiratory diseases, malignancy or HIV infection (only one patient). Table 2 shows clinical, radiological and laboratory findings. The most frequent symptoms were fever $(80 \%)$, cough $(69 \%)$, fatigue $(59 \%)$ and dyspnoea $(52 \%)$ but other symptoms such as anorexia $(36 \%)$ or diarrhoea $(21 \%)$ were not uncommon. The most common findings on chest radiographs were bilateral interstitial infiltrates $(65 \%)$ and no radiographic abnormality was found in 11 patients (11\%). Only two chest CT were performed showing pulmonary thromboembolism in both cases. Lung ultrasound (LUS) was performed in 46 patients and only 3 patients $(6.5 \%)$ had no abnormalities. The most frequent LUS abnormalities were score 1 findings (bilateral vertical "B-kerley" lines) in 38 patients $(82.6 \%)$ followed by score 2 findings (thickened and irregular pleural line) in 5 patients (10.9\%). The most frequent laboratory abnormalities were lymphocytopenia, elevated levels of C-reactive protein, creatine kinase, lactate dehydrogenase and D-Dimer. Treatment during hospital admission is shown in Table 3 - All patients received oxygen (using Venturi mask or nasal cannula) and one third required high oxygen concentrations (higher than 50\%). One third of patients received only symptomatic treatment and the remaining $69 \%$ received medical treatment, the most frequent being the combination of hydroxychloroquine and azithromycin in 66 cases. No medication-related adverse event was observed.

During hospitalization, 26 patients $(26 \%)$ died and $10(10 \%)$ were transferred to the ICU. The outcome in the UCI was as follows: 4 patients died and 6 were discharged at home. After a median length of stay of 7 days, the remaining 64 patients $(64 \%)$ were discharged at home with no readmissions.

\section{Bivariate and multivariate risk for mortality or ICU admission}

In the bivariate analysis the following variables were associated with the composite end-point mortality or ICU admission (Table 1, 2 and 3 ): advanced age, more comorbidities (specially diabetes mellitus, cardiovascular and respiratory chronic diseases), higher PROFUND score at baseline, anticoagulant prescription before admission, respiratory insufficiency and radiographic abnormalities on admission, more prominent laboratory abnormalities (elevated levels of creatinine, C-reactive protein, procalcitonin, creatine kinase, aspartate aminotransferase and lactate dehydrogenase), requiring higher oxygen concentrations (or prone positioning) and no receiving medical treatment. In the multivariate adjusted analysis only two variables persisted as a significant risk factor for the composite endpoint: a higher PROFUND score punctuation (OR 1.4; 95\% CI: 1.1-1.8) and higher C-reactive protein values on admission (OR 1.2; 95\%CI: 1.1-1.4).

\section{Discussion}

This study represents the first case series of sequentially hospitalized laboratory confirmed COVID-19 patients from a regional hospital in Spain.

In comparison with other series of hospitalized patients, our study includes and represents older patients, 
with a median age of 75 years old (range 28-96) and more than a third over 80 years old. Series from China, United States and Italy included younger patients ranging from 47 to 55 in China ${ }^{1,4,7}$ and from 61 to 64 in United States and Italy ${ }^{6,12-16}$. In addition, the median age of a larger retrospective study from Spanish University Hospitals (mostly from Madrid) was 69.4 years old ${ }^{17}$.

In a similar way to these previous series, our patients had many comorbidities (arterial hypertension, diabetes mellitus and cardiovascular diseases were the most frequent) and a low proportion of smokers, history of chronic respiratory diseases or HIV infection ${ }^{1,4,7,12-19}$. The clinical and laboratory presentation were also similar to the already described, and, unlike other centres, we have performed few chest CT scans (in part, to avoid transferring patients outside the isolation area) and more LUS. In our opinion, LUS can be very useful in characterizing lung involvement of COVID-19 even when chest radiograph is normal ${ }^{11}$.

The COVID-19 related signs and symptoms found in our study are similar to those reported in previous studies with the exception of a low proportion (3\%) of smell and taste alterations. This is surprising when compared to the high proportion of our healthcare workers affected by COVID-19 who presented these symptoms $(53 \%)^{8}$. There is a wide range of these symptoms ranging from $7 \%$ in hospitalized patients from Spain to $64 \%$ in mildly symptomatic outpatients from Italy ${ }^{20}$. It is probable that less severe patients tend to express these symptoms more often than more severely ill ones.

We found a high in-hospital mortality in our study $(26 \%)$. This data is clearly higher than those reported at the start of the pandemic in China (1.4-11\% $)^{1,4}$ and the first communications from the United States $(10-21 \% \text { in New York City and } 15.6 \% \text { in California })^{13-14}$. This proportion is also slightly higher than the $20 \%$ morality rate more recently reported in the abovementioned studies from Italy and Spain ${ }^{16,17}$. The old population and high comorbidity of our patients may explain, in part, this high mortality rate. We believe that mortality could have been even higher if more patients had been admitted from long-term care facilities ( $17 \%$ in the present study) were mortality rates are higher than $30 \%^{5}$.

Apart from age and comorbidities we have found other variables associated with the composite outcome (death or ICU admission) including respiratory insufficiency or radiographic abnormalities at presentation, more prominent laboratory abnormalities, and requiring higher oxygen concentrations. In the multivariate analysis only a high comorbidity burden (measured with the PROFUND score) and high C-reactive protein values, remained statistically significant risk factor. It is important to early identify these patients and try to modify their prognosis. We have also found that those patients treated with hydroxychloroquine and azithromycin had a better prognosis, but this finding should be interpreted with caution. Treatment assignation was not randomized, and it was prescribed according to regional protocols, at treating physician discretion and after consent of the patient.

The main strength of this study is that it is prospective (including all consecutively hospitalized patients) and that it offers unpublished information so far, including advanced age patients, from a non-university regional hospital and from Spain. The main limitation of this study is that the data only represent a single centre in a rural region of Spain, so the findings cannot be generalized. More studies from Spain and other European countries are necessary to verify the clinical characteristics, in-hospital mortality rates and prognostic factors of COVID-19.

In conclusion, case-fatality rate of patients hospitalized with COVID-19 in the early days of the Spanish epidemic was high (26\%). A high comorbidity burden and high C-reactive protein values were factors related with increased risk of death or ICU admission.

\section{References}

1.- Chen N, Zhou M, Dong X, Qu J, Gong F, Han Y, et al. Epidemiological and clinical characteristics of 99 cases of 2019 novel coronavirus pneumonia in Wuhan, China: a descriptive study. Lancet. 2020;395:507-513. doi: 10.1016/S0140-6736(20)30211-7.

2.- Mahase E. China coronavirus: WHO declares International emergency as death toll exceeds 200. BMJ. 2020 Jan 31;368:m408. doi: 10.1136/bmj.m408. PMID: 32005727. 
3.- Spiteri G, Fielding J, Diercke M, Campese C, Enouf V, Gaymard A, et al. First cases of coronavirus disease 2019 (COVID-19) in the WHO European Region, 24 January to 21 February 2020. Euro Surveill. 2020;25:2000178. doi:10.2807/1560-7917.ES.2020.25.9.2000178

4.- Guan WJ, Ni ZY, Hu Y, Liang W, Ou C, He J, et al. Clinical Characteristics of Coronavirus Disease 2019 in China. N Engl J Med. 2020;382:1708-1720. doi: 10.1056/NEJMoa2002032.

5.- McMichael TM, Currie DW, Clark S, Pogosjans S, Kay M, Schwartz NG, et al. Epidemiology of Covid19 in a Long-Term Care Facility in King County, Washington. N Engl J Med. 2020;382:2005-2011. doi: 10.1056/NEJMoa2005412.

6.- Grasselli G, Zangrillo A, Zanella A, Antonelli M, Cabrini L, Castelli A, et al. Baseline Characteristics and Outcomes of 1591 Patients Infected With SARS-CoV-2 Admitted to ICUs of the Lombardy Region, Italy. JAMA. 2020;323:1574-1581. doi: 10.1001/jama.2020.5394.

7.- Wang X, Fang J, Zhu Y, Chen L, Ding F, Zhou R, et al. Clinical characteristics of non-critically ill patients with novel coronavirus infection (COVID-19) in a Fangcang Hospital. Clin Microbiol Infect. 2020;26:1063-1068. doi: 10.1016/j.cmi.2020.03.032.

8.- Trullàs JC, Vilardell I, Blasco M, Heredia J. COVID-19 in health workers from the Olot Regional Hospital (Girona). Rev Clin Esp. 2020 Jul 17:S0014-2565(20)30205-8. doi: 10.1016/j.rce.2020.07.002.

9.- Ministerio de Sanidad. Documentos técnicos para profesionales. Documentos de preparación y respuesta al brote. Procedimiento de actuación frente a casos de infección por el nuevo coronavirus (SARS-CoVv-2). Actualizado a 31 de marzo de 2020 . Available at: https://www.mscbs.gob.es/en/profesionales/saludPublica/ccayes/alertasActual/nCov-

China/documentos.htm

10.- Bernabeu-Wittel M, Ollero-Baturone M, Moreno-Gaviño L, Barón-Franco B, Fuertes A, MurciaZaragoza J, et al. Development of a new predictive model for polypathological patients. The PROFUND index. Eur J Intern Med. 2011;22:311-317. doi:10.1016/j.ejim.2010.11.012

11.- Soldati G, Smargiassi A, Inchingolo R, Buonsenso D, Perrone T, Brigantiet DF, et al. Proposal for International Standardization of the Use of Lung Ultrasound for Patients With COVID-19: A Simple, Quantitative, Reproducible Method. Ultrasound Med. 2020;39:1413-1419. doi: 10.1002/jum.15285.

12.- Goyal P, Choi JJ, Pinheiro LC, Schenck EJ, Chen R, Jabri A, et al. Clinical Characteristics of Covid-19 in New York City. N Engl J Med. 2020;382:2372-2374. doi: 10.1056/NEJMc2010419.

13.- Richardson S, Hirsch JS, Narasimhan M, Crawford JM, McGinn T, Davidson KW, et al. Presenting Characteristics, Comorbidities, and Outcomes Among 5700 Patients Hospitalized With COVID-19 in the New York City Area. JAMA. 2020;323:2052-2059. doi: 10.1001/jama.2020.6775.

14.- Myers LC, Parodi SM, Escobar GJ, Liu VX. Characteristics of Hospitalized Adults With COVID-19 in an Integrated Health Care System in California. JAMA. 2020;323:2195-2198. doi: 10.1001/jama.2020.7202.

15.- Bhatraju PK, Ghassemieh BJ, Nichols M, Kim R, Jerome KR, Nalla AK, et al. Covid-19 in Critically Ill Patients in the Seattle Region - Case Series. N Engl J Med. 2020;382:2012-2022. doi: 10.1056/NEJMoa2004500.

16.- Giacomelli A, Ridolfo AL, Milazzo L, Oreni L, Bernacchia D, Siano M, et al 30-day mortality in patients hospitalized with COVID-19 during the first wave of the Italian epidemic: A prospective cohort study. Pharmacol Res. 2020;158:104931. doi: 10.1016/j.phrs.2020.104931.

17.- Casas-Rojo JM, Anton-Santos JM, Millan-Nunez-Cortes J, Lumbreras-Bermejo C, Ramos-Rincon JM, Roy-Vallejo E, et al. Clinical characteristics of patients hospitalized with COVID-19 in Spain: Results from the SEMI-COVID-19 Registry. Rev Clin Esp. 2020:S0014-2565(20)30206-X. doi: 10.1016/j.rce.2020.07.003. 
18.- Halpin DMG, Faner R, Sibila O, Badia JR, Agusti A. Do chronic respiratory diseases or their treatment affect the risk of SARS-CoV-2 infection? Lancet Respir Med. 2020;8:436-438. doi: 10.1016/S22132600(20)30167-3.

19.- Blanco JL, Ambrosioni J, Garcia F, Martinez E, Soriano A, Mallolas J, et al. COVID-19 in patients with HIV: clinical case series. Lancet HIV. 2020;7:e314-e316. doi: 10.1016/S2352-3018(20)30111-9.

20.- Spinato G, Fabbris C, Polesel J, Cazzador D, Borsetto D, Hopkins C, et al. Alterations in smell or taste in mildly symptomatic outpatients with SARS-CoV-2 infection. JAMA. 2020;323:2089-2090. doi: 10.1001/jama.2020.6771.

Table 1. Demographics and baseline characteristics of 100 patients with COVID-19 admitted to the HOCG

\begin{tabular}{|c|c|c|c|c|}
\hline & Total & $\begin{array}{l}\text { Alive and } \\
\text { discharged }\end{array}$ & Death or ICU & $\mathrm{p}$ value \\
\hline $\begin{array}{l}\text { Number of } \\
\text { patients }\end{array}$ & 100 & 64 & 36 & - \\
\hline Age (years) & 75 [20]; 28-96 & 73 [27]; 28-96 & 79 [19]; 46-93 & 0.003 \\
\hline$<50$ years $50-69$ & $9(9 \%) 30(30 \%) 23$ & $8(13 \%) 21(33 \%)$ & $1(3 \%) 9(25 \%) 8$ & 0.02 \\
\hline years $70-79$ years & $(23 \%) 31(31 \%) 7$ & $15(23 \%) 17(27 \%)$ & $(22 \%) 14(39 \%) 4$ & \\
\hline $\begin{array}{l}80-89 \text { years }>90 \\
\text { years }\end{array}$ & $(7 \%)$ & $3(5 \%)$ & $(11 \%)$ & \\
\hline Male gender & $52(52 \%)$ & $31(48 \%)$ & $21(58 \%)$ & 0.41 \\
\hline $\begin{array}{l}\text { Place of } \\
\text { residence on } \\
\text { admission }\end{array}$ & $\begin{array}{l}\text { Place of } \\
\text { residence on } \\
\text { admission }\end{array}$ & $\begin{array}{l}\text { Place of } \\
\text { residence on } \\
\text { admission }\end{array}$ & $\begin{array}{l}\text { Place of } \\
\text { residence on } \\
\text { admission }\end{array}$ & $\begin{array}{l}\text { Place of } \\
\text { residence on } \\
\text { admission }\end{array}$ \\
\hline $\begin{array}{l}\text { Home Long-term } \\
\text { care facility }\end{array}$ & $83(83 \%) 17(17 \%)$ & $54(84 \%) 10(16 \%)$ & $29(81 \%) 7(19 \%)$ & 0.56 \\
\hline Medical history & Medical history & Medical history & Medical history & Medical history \\
\hline Smoking history & $80(80 \%) 16(16 \%)$ & $52(81 \%) 8(13 \%) 4$ & $28(78 \%) 8(22 \%) 0$ & 0.17 \\
\hline Never smoked & $4(4 \%)$ & $(6 \%)$ & $(0 \%)$ & \\
\hline \multicolumn{5}{|l|}{ Former smoker } \\
\hline \multicolumn{5}{|l|}{ Active smoker } \\
\hline Hypertension & $63(63 \%)$ & $38(59 \%)$ & $25(69 \%)$ & 0.32 \\
\hline Diabetes mellitus & $22(22 \%)$ & $10(16 \%)$ & $12(33 \%)$ & 0.04 \\
\hline Obesity & $16(16 \%)$ & $12(19 \%)$ & $4(11 \%)$ & 0.32 \\
\hline $\begin{array}{l}\text { Cardiovascular } \\
\text { disease+ }\end{array}$ & $28(28 \%)$ & $13(20 \%)$ & $15(42 \%)$ & 0.02 \\
\hline $\begin{array}{l}\text { Chronic } \\
\text { respiratory }\end{array}$ & $12(12 \%)$ & $4(6 \%)$ & $8(22 \%)$ & 0.02 \\
\hline $\begin{array}{l}\text { disease }++ \\
\text { Chronic kidney }\end{array}$ & & & & \\
\hline $\begin{array}{l}\text { Chronic kidney } \\
\text { disease }\end{array}$ & $15(15 \%)$ & $7(11 \%)$ & $8(22 \%)$ & 0.13 \\
\hline Cirrhosis & $2(2 \%)$ & $1(2 \%)$ & $1(3 \%)$ & 0.68 \\
\hline Malignancy & $14(14 \%)$ & $7(11 \%)$ & $7(19 \%)$ & 0.50 \\
\hline HIV infection & $1(1 \%)$ & $1(2 \%)$ & $0(0 \%)$ & 0.45 \\
\hline Dementia & $11(11 \%)$ & $6(10 \%)$ & $5(14 \%)$ & 0.49 \\
\hline PROFUND score $§$ & $56(56 \%) 22(22 \%)$ & $43(67 \%) 11(17 \%)$ & $13(36 \%) 11(31 \%)$ & 0.03 \\
\hline 0-2 $3-6 \quad 7-10 \quad 11-30$ & $9(9 \%) 13(13 \%)$ & $4(6 \%) 6(10 \%)$ & $5(14 \%) 7(19 \%)$ & \\
\hline Treatment & Treatment & Treatment & Treatment & Treatment \\
\hline before & before & before & before & before \\
\hline admission & admission & admission & admission & admission \\
\hline
\end{tabular}




\begin{tabular}{lllll}
\hline & Total & $\begin{array}{l}\text { Alive and } \\
\text { discharged }\end{array}$ & Death or ICU & p value \\
\hline ACEI & $30(30 \%)$ & $21(33 \%)$ & $9(25 \%)$ & 0.41 \\
ARB & $8(8 \%)$ & $6(9 \%)$ & $2(6 \%)$ & 0.50 \\
Immunosuppressive & $3(3 \%)$ & $2(3 \%)$ & $1(3 \%)$ & 0.92 \\
drugs & & $4(6 \%)$ & $2(6 \%)$ & 0.88 \\
Corticosteroids & $6(6 \%)$ & $12(19 \%)$ & $16(44 \%)$ & 0.006 \\
Anticoagulants & $28(28 \%)$ & &
\end{tabular}

Quantitative variables are expressed as median [interquartile range]; range. Qualitative variables are expressed as number and percentage. +Including heart, cerebrovascular and peripheral artery diseases. ++Including COPD and asthma. §PROFUND score predicts one-year mortality for a patient based on demographic, clinical, laboratory, social and functional variables, scores between 0 and 30 points and establishes 4 levels of risk of death: low (0-2 points), intermediate (3-6 points), high (7-10 points) and very high (11-30 points).Abbreviations : HOCG: Hospital d'Olot i Comarcal de la Garrotxa; COPD: chronic obstructive pulmonary disease; ACEI: Angiotensin-converting-enzyme inhibitors; ARB: Angiotensin II receptor blockers

Table 2. Clinical characteristics, radiological and laboratory findings among 100 patients with COVID-19 admitted to the HOCG

\begin{tabular}{|c|c|c|c|c|}
\hline & Total & Alive & Death or ICU & p value \\
\hline $\begin{array}{l}\text { Number of } \\
\text { patients }\end{array}$ & 100 & 64 & 36 & - \\
\hline $\begin{array}{l}\text { Signs and } \\
\text { symptoms on } \\
\text { admission }\end{array}$ & $\begin{array}{l}\text { Signs and } \\
\text { symptoms on } \\
\text { admission }\end{array}$ & $\begin{array}{l}\text { Signs and } \\
\text { symptoms on } \\
\text { admission }\end{array}$ & $\begin{array}{l}\text { Signs and } \\
\text { symptoms on } \\
\text { admission }\end{array}$ & $\begin{array}{l}\text { Signs and } \\
\text { symptoms on } \\
\text { admission }\end{array}$ \\
\hline Asymptomatic & $4(4 \%)$ & $4(6 \%)$ & $0(0 \%)$ & 0.13 \\
\hline Cough & $69(69 \%)$ & $44(72 \%)$ & $23(64 \%)$ & 0.41 \\
\hline Fever & $80(80 \%)$ & $50(78 \%)$ & $30(83 \%)$ & 0.67 \\
\hline Dyspnoea & $52(52 \%)$ & $29(45 \%)$ & $23(64 \%)$ & 0.07 \\
\hline Fatigue & $59(59 \%)$ & $38(59 \%)$ & $21(58 \%)$ & 0.92 \\
\hline Anorexia & $36(36 \%)$ & $26(41 \%)$ & $10(28 \%)$ & 0.20 \\
\hline Diarrhoea & $21(21 \%)$ & $14(22 \%)$ & $7(19 \%)$ & 0.78 \\
\hline Headache & $8(8 \%)$ & $7(11 \%)$ & $1(3 \%)$ & 0.15 \\
\hline $\begin{array}{l}\text { Alterations in } \\
\text { Smell or Taste }\end{array}$ & $3(3 \%)$ & $3(5 \%)$ & $0(0 \%)$ & 0.19 \\
\hline $\begin{array}{l}\text { Respiratory } \\
\text { insufficiency }\end{array}$ & $64(64 \%)$ & $30(47 \%)$ & $34(94 \%)$ & $<0.001$ \\
\hline $\begin{array}{l}\text { Chest } \\
\text { radiograph on } \\
\text { admission }\end{array}$ & $\begin{array}{l}\text { Chest } \\
\text { radiograph on } \\
\text { admission }\end{array}$ & $\begin{array}{l}\text { Chest } \\
\text { radiograph on } \\
\text { admission }\end{array}$ & $\begin{array}{l}\text { Chest } \\
\text { radiograph on } \\
\text { admission }\end{array}$ & $\begin{array}{l}\text { Chest } \\
\text { radiograph on } \\
\text { admission }\end{array}$ \\
\hline Normal & $11(11 \%)$ & $10(16 \%)$ & $1(3 \%)$ & 0.04 \\
\hline $\begin{array}{l}\text { Bilateral } \\
\text { interstitial } \\
\text { infiltrates }\end{array}$ & $65(65 \%)$ & $39(61 \%)$ & $26(72 \%)$ & 0.59 \\
\hline $\begin{array}{l}\text { Alveolar } \\
\text { unilateral } \\
\text { infiltrate }\end{array}$ & $12(12 \%)$ & $8(12 \%)$ & $4(11 \%)$ & \\
\hline Other findings & $12(12 \%)$ & $7(11 \%)$ & $5(14 \%)$ & \\
\hline Pleural effusion & $4(4 \%)$ & $3(5 \%)$ & $1(3 \%)$ & 0.64 \\
\hline
\end{tabular}




\begin{tabular}{|c|c|c|c|c|}
\hline & Total & Alive & Death or ICU & $p$ value \\
\hline $\begin{array}{l}\text { Thromboembolic } \\
\text { disease }+ \\
\text { Lung } \\
\text { ultrasound } \\
(\mathrm{N}=46)++\end{array}$ & $3(3 \%)$ & $1(2 \%)$ & $2(6 \%)$ & 0.27 \\
\hline Score 0 & $3(6.5 \%)$ & $3(9 \%)$ & $0(0 \%)$ & 0.52 \\
\hline Score 1 & $38(82.6 \%)$ & $27(79 \%)$ & $11(92 \%)$ & \\
\hline Score 2 & $5(10.9 \%)$ & $4(12 \%)$ & $1(8 \%)$ & \\
\hline Score 3 & $0(0 \%)$ & - & - & \\
\hline Laboratory & Laboratory & Laboratory & Laboratory & Laboratory \\
\hline $\begin{array}{l}\text { findings on } \\
\text { admission }\end{array}$ & $\begin{array}{l}\text { findings on } \\
\text { admission }\end{array}$ & $\begin{array}{l}\text { findings on } \\
\text { admission }\end{array}$ & $\begin{array}{l}\text { findings on } \\
\text { admission }\end{array}$ & $\begin{array}{l}\text { findings on } \\
\text { admission }\end{array}$ \\
\hline $\begin{array}{l}\text { Haemoglobin } \\
(\mathrm{g} / \mathrm{dl})\end{array}$ & $13[2]$ & $13[2]$ & $13[3]$ & 0.52 \\
\hline $\begin{array}{l}\text { White-cell count } \\
\left(\text { per } \mathrm{mm}^{3}\right)\end{array}$ & 7625 [4430] & $6870[3640]$ & $9090[6650]$ & 0.05 \\
\hline $\begin{array}{l}\text { Lymphocyte } \\
\text { count }\left(\text { per } \mathrm{mm}^{3} \text { ) }\right.\end{array}$ & 850 [610] & $1000[560]$ & $815[715]$ & 0.24 \\
\hline $\begin{array}{l}\text { Platelet count } \\
\left(\text { per } \mathrm{mm}^{3}\right)\end{array}$ & $209,000[111,250]$ & $215,500[106,750]$ & $191,000[121,500]$ & 0.27 \\
\hline D-Dimer (ng/ml) & 1138 [1184] & $1186[1027]$ & $1035[1664]$ & 0.64 \\
\hline $\begin{array}{l}\text { Creatinine } \\
(\mathrm{mg} / \mathrm{dl})\end{array}$ & $0.9[0,6]$ & $0.8[0.4]$ & $1.1[0.6]$ & 0.001 \\
\hline $\begin{array}{l}\text { C-reactive protein } \\
(\mathrm{mg} / \mathrm{dl})\end{array}$ & $9.4[12.5]$ & $7.5[9.9]$ & $15.8[20.9]$ & 0.004 \\
\hline $\begin{array}{l}\text { Procalcitonin } \\
(\mathrm{ng} / \mathrm{ml})\end{array}$ & $0.1[0.3]$ & $0.08[0.2]$ & $0.36[0.8]$ & $<0.001$ \\
\hline $\begin{array}{l}\text { Creatine kinase } \\
(\mathrm{U} / \mathrm{L})\end{array}$ & $86[160]$ & $68[67]$ & $179[394]$ & 0.03 \\
\hline $\begin{array}{l}\text { Aspartate } \\
\text { aminotransferase } \\
(\mathrm{U} / \mathrm{L})\end{array}$ & $38[25]$ & $33[24]$ & $46[67]$ & 0.003 \\
\hline $\begin{array}{l}\text { Lactate } \\
\text { dehydrogenase } \\
(\mathrm{U} / \mathrm{L})\end{array}$ & $402[264]$ & $366[196]$ & $526[306]$ & $<0.001$ \\
\hline
\end{tabular}

Quantitative variables are expressed as median [interquartile range]. Qualitative variables are expressed as number and percentage. + Two pulmonary thromboembolism and one low extremity deep vein thrombosis. ++ Lung ultrasound Scores : Score 0: normal findings. Score 1: The pleura line is continuous and bilateral vertical "B Kerley" lines are visible; Score 2: The pleura line is not continuous and appears thick and irregular; Score 3: Consolidated areas are visible. Abbreviations : HOCG: Hospital d'Olot i Comarcal de la Garrotxa; ICU: intensive care unit.

Table 3. Treatment

\begin{tabular}{lllll}
\hline & Total & Alive & Death or ICU & p value \\
\hline $\begin{array}{l}\text { Number of } \\
\text { patients }\end{array}$ & 100 & 64 & 36 & - \\
$\begin{array}{l}\text { Oxygen } \\
\text { therapy FiO2 }\end{array}$ & $\begin{array}{l}\text { Oxygen } \\
\text { therapy FiO2 }\end{array}$ & $\begin{array}{l}\text { Oxygen } \\
\text { therapy FiO2 }\end{array}$ & $\begin{array}{l}\text { Oxygen } \\
\text { therapy FiO2 }\end{array}$ & $\begin{array}{l}\text { Oxygen } \\
\text { therapy FiO2 }\end{array}$
\end{tabular}




\begin{tabular}{|c|c|c|c|c|}
\hline & Total & Alive & Death or ICU & $p$ value \\
\hline $\begin{array}{l}\text { FiO2 on admission } \\
21 \% 30 \% 40 \% 50 \% \\
100 \%\end{array}$ & $\begin{array}{l}54(54 \%) 29(29 \%) 7 \\
(7 \%) 4(4 \%) 6(6 \%)\end{array}$ & $\begin{array}{l}42(66 \%) 14(22 \%) 6 \\
(9 \%) 1(2 \%) 1(2 \%)\end{array}$ & $\begin{array}{l}12(33 \%) 15(42 \%) \\
1(3 \%) 3(8 \%) 5 \\
(14 \%)\end{array}$ & 0.001 \\
\hline $\begin{array}{l}\text { Highest FiO2 during } \\
\text { admission } 21 \% 30 \% \\
40 \% 50 \% 100 \% \\
\text { High flow oxygen }\end{array}$ & $\begin{array}{l}32(32 \%) 26(27 \%) \\
10(10 \%) 5(5 \%) 21 \\
(21 \%) 4(4 \%)\end{array}$ & $\begin{array}{l}28(44 \%) 20(31 \%) \\
8(12 \%) 2(3 \%) 4 \\
(6 \%) 2(3 \%)\end{array}$ & $\begin{array}{l}4(12 \%) 6(18 \%) 2 \\
(6 \%) 3(9 \%) 17 \\
(50 \%) 2(6 \%)\end{array}$ & $<0.001$ \\
\hline $\begin{array}{l}\text { Prone positioning } \\
\text { Medical } \\
\text { treatment }\end{array}$ & $5(5 \%)$ & $0(0 \%)$ & $5(14 \%)$ & 0.002 \\
\hline $\begin{array}{l}\text { Only } \\
\text { symptomatic }\end{array}$ & $31(31 \%)$ & $18(28 \%)$ & $13(36 \%)$ & 0.41 \\
\hline Medication+ & $69(69 \%)$ & $46(72 \%)$ & $23(64 \%)$ & \\
\hline $\begin{array}{l}\text { Azithromycin HCQ } \\
+ \text { azithromycin } \\
\mathrm{HCQ}+ \\
\text { azithromycin + } \\
\text { Lopinavir/r }\end{array}$ & $\begin{array}{l}2(3 \%) 66(96 \%) 1 \\
(1 \%)\end{array}$ & $\begin{array}{l}0(0 \%) 46(100 \%) 0 \\
(0 \%)\end{array}$ & $\begin{array}{l}2(9 \%) 20(87 \%) 1 \\
(4 \%)\end{array}$ & 0.04 \\
\hline $\begin{array}{l}\text { Days from the } \\
\text { onset of } \\
\text { symptoms to } \\
\text { start of treatment }\end{array}$ & $9[4]$ & $9[4]$ & $7[7]$ & 0.08 \\
\hline $\begin{array}{l}\text { Intravenous } \\
\text { antibiotics }\end{array}$ & $26(26 \%)$ & $13(20 \%)$ & $13(36 \%)$ & 0.08 \\
\hline Glucocorticoids & $12(12 \%)$ & $6(9 \%)$ & $6(17 \%)$ & 0.28 \\
\hline
\end{tabular}

Quantitative variables are expressed as median [interquartile range]. Qualitative variables are expressed as number and percentage. +Dose regimen: Azithromycin 500mg QD for one day followed by 250mg QD for four days; HQC 400mg BID for one day followed by 200mg BID for four days. Abbreviations : FiO2: Fraction of inspired oxygen; HCQ: hydroxychloroquine; Lopinavir/r: lopinavir/ritonavir; QD: once a day; BID: two times a day. 